\title{
HAK PEREMPUAN DALAM MEMILIH SUAMI (Telaah Hadis Ijbâr Wali)
}

\author{
Muhammad Kudhori \\ (STAI Al-Fithrah Surabaya, Jl. Kedinding Lor 99 Surabaya 60129, E-mail: \\ khudhori84@gmail.com)
}

\begin{abstract}
Abstrak:
Kasus perjodohan oleh orang tua terhadap anak perempuannya masih dijumpai di dalam masyarakat muslim Indonesia. Tak jarang, praktek nikah paksa yang dilakukan oleh oknum orang tua justru berakhir dengan penyiksaan dhahir maupun batin kepada anak perempuan. Tulisan ini membahas apakah memilih calon suami merupakan hak perempuan secara mutlak ataukah ada campur tangan dari orang tua? Kebebasan memilih pasangan hidup bagi seorang perempuan sebenarnya telah dijamin oleh Syara'. Para pelaku praktek nikah paksa biasanya menggunakan hadis: "Perawan, bapaknya yang menikahkannya." sebagai upaya untuk membenarkan tindakannya. Namun ternyata hadis tersebut termasuk dalam kategori hadis syâdz yang tertolak, karena bertentangan dengan riwayat-riwayat sahih yang memberikan kebebasan mutlak bagi perempuan untuk memilih suaminya. Seorang perempuan yang tidak mematuhi perintah orang tuanya untuk dinikahkan dengan laki-laki yang tidak dicintainya sama sekali bukan perempuan yang durhaka, karena pada dasarnya bakti kepada orang tua didasari dengan cinta dan kasih sayang, bukan keterpaksaan.
\end{abstract}

Kata Kunci:

perempuan, orang tua, suami, nikah paksa, kebebasan

\begin{abstract}
:
The cases of matchmaking by parents to their daughters are still found in Indonesian Muslim societies. Frequently, the practice of forced marriages committed by unscrupulous parents ended up in physical and psychological tortures experienced by women. This paper discusses whether choosing a spouse is the absolute right of women or there should be any interferences by parents. The freedom of choosing a spouse for a woman has actually been guaranteed by Syaria. The perpetrators of forced marriage practice usually use the
\end{abstract}


hadith: " for the virgin, it is her father who marries her to a man " in an attempt to justify their actions. However, the hadith belongs to the category of a syâdz hadith which is rejected as it contradicts the valid narrations which give women the absolute freedom to choose their husbands. A woman who does not obey her parents' orders to marry a man she does not love is not a disobedient woman since, basically, her devotion to her parents should be based on love and affection, not compulsion.

\section{Key Words:}

Women, Parents, Husbands, Forced marriages, Freedom

\section{Pendahuluan}

Kasus perjodohan oleh orang tua kepada anak perempuannya masih sering dijumpai dalam kehidupan masyarakat Indonesia, bahkan di dunia. ${ }^{1}$ Beberapa dijumpai kasus nikah paksa yang dilakukan oleh orang tua terhadap anak perempuannya. Tak jarang, praktek nikah paksa yang dilakukan oleh oknum orang tua -yang oleh orang tua bertujuan membahagiakan anak perempuannyajustru berakhir dengan penyiksaan fisik maupun batin kepada anak perempuannya. Efeknya, umur pernikahan tidak berjalan lama.

Jika sudah demikian, ujung-ujungnya yang dirugikan adalah kaum perempuan. Seorang perempuan kerap kali tidak bisa berbuat apa-apa ketika dihadapkan pada persoalan seperti ini. Di satu sisi dengan mematuhi perintah orang tuanya menerima perjodohan tersebut- ia beranggapan bahwa hal itu adalah sebuah bentuk bakti kepada orang tua. Namun di sisi lain, sebenarnya perempuan itu

1Para pakar memperkirakan setiap tahun korban nikah paksa di Inggris berkisar antara 5.000 sampai 8.000 orang. Sebagian besar perempuan yang dipaksa menikah berusia di bawah 21 tahun dan sebagian berusia di bawah 15 tahun. Sebagian keluarga korban berasal dari Pakistan, Bangladesh dan India. Tetapi ada sejumlah kasus yang dilaporkan terjadi pada komunitas Afrika, Amerika Latin dan juga Eropa Timur.

(http://www.bbc.co.uk/indonesia/dunia/2012/06/120608_forced_marriages.shtml) Gadis cilik asal Yaman berusia 8 tahun tewas akibat luka dalam saat malam pertama pernikahannya. Si gadis dinikahkan paksa dengan pria berumur lebih dari 5 kali lipat usianya. Seperti diberitakan News.com.au, Selasa (10/9/2013) si gadis menderita sobek pada alat kelamin dan pendarahan hebat. Dia tewas di Kota Hardh Provinsi Hajjah di barat laut Yaman. (http://news.liputan6.com/read/688379/tragis-gadis-8tahun-korban-nikah-paksa-tewas-saat-malam-pertama)

$$
\text { al-1hkâm Vol.12 No.1 Juni } 2017
$$


menjerit, karena merasa haknya telah dirampas dengan semena-mena oleh keegoisan orang tua. Beberapa perempuan korban nikah paksa yang pernah dijumpai penulis tidak dapat berbuat banyak dan pasrah Dalam posisi semacam ini, mereka selalu dihantui perasaan sebagai anak yang durhaka bila tidak mematuhi keinginan orang tuanya. ${ }^{2}$

Tulisan ini membahas bagaimana sebenarnya seorang perempuan dalam memilih calon suaminya. Apakah memilih calon suami merupakan haknya secara mutlak ataukah dengan campur tangan orang tuanya?

\section{Kebebasan Perempuan Dalam Memilih Suami Dijamin Syara'}

'Abd al-Halîm Muhammad Abû Shuqqah dalam Tahrîr alMar'ah fî 'Asr al-Risâlah menyebutkan setidaknya ada empat riwayat hadis hak perempuan dalam memilih suaminya. ${ }^{3}$

Pertama adalah hadis riwayat al-Bukhârî dengan redaksi:

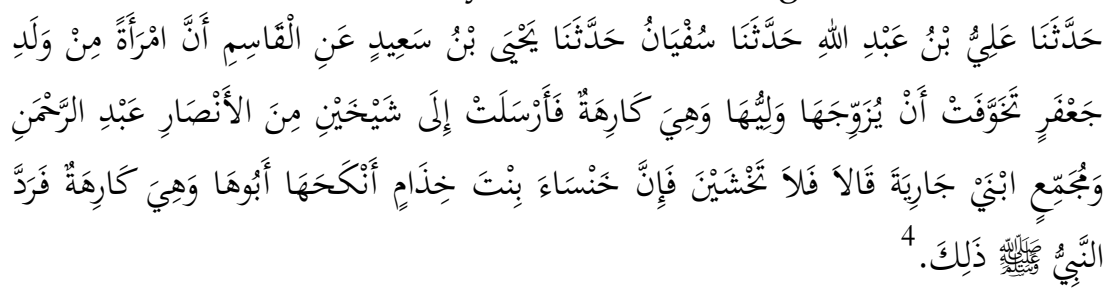

“... dari al-Qasim, bahwa seorang perempuan dari anak Ja'far merasa ketakutan (waswas) walinya menikahkannya sedangkan dia tidak suka, maka ia segera mengutus seseorang menemui dua shaikh dari kalangan Ansar, 'Abd al-Rahman dan Mujammi', dua anak Jariyah. Maka keduanya berkata; "Janganlah khawatir, karena Khansa' binti Khidham pernah dinikahkan ayahnya sedang dia tidak suka, maka Nabi Saw. menolak pernikahannya."

\footnotetext{
2 Dalam sebuah hadis riwayat al-Bukhârî, Rasulullah pernah ditanya tentang dosa besar, maka beliau bersabda:

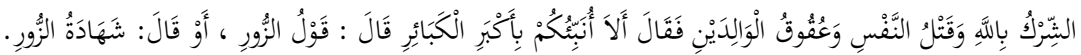

“Menyekutukan Allah, membunuh jiwa dan durhaka kepada kedua orang tua” Lalu beliau bersabda: "Maukah aku beritahukan kepada kalian yang termasuk dari dosa besar?" beliau bersabda: "Perkataan dusta" atau beliau bersabda: "Kesaksian palsu." Syu'bah mengatakan; "Dan saya menyangka bahwa beliau mengatakan; "Kesaksian palsu." Muhammad bin Ismâ'îl al-Bukhârî, al-Jâmî̀ al-Shahîh, Vol. 8, (Kairo: Dar alSha'b, 1987), 5

3 'Abd al-ㅂalîm Muhammad Abû Shuqqah, Tahrîr al-Mar'ah fi 'As\}r al-Risâlah, Vol. 1 (Kuwait: Dar al-Qalam, 1999), 173-174.

4 al-Bukhârî, al-Jâmî’ al-Shahîh, Vol. 9, (Kairo: Dar al-Sha'b, 1987), 32-33.
} 
Kedua adalah hadis riwayat al-Bukhârî dengan redaksi:

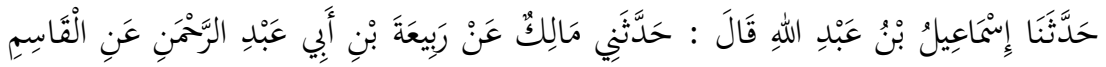

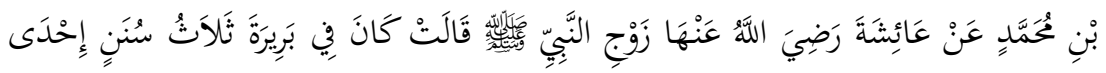

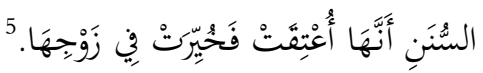

"Telah menceritakan kepada kami Isma'il bin 'Abd Allah ia berkata; Telah menceritakan kepadaku Malik dari Rabi'ah bin Abi 'Abd al-Rahman dari alQasim bin Muhammad dari 'A'isyah, isteri Nabi, ia berkata: "Sesungguhnya pada diri Barirah terdapat tiga sunnah. Salah satunya ia telah dimerdekakan dan diberi tawaran untuk memilih terhadap suaminya."

Ketiga adalah hadis riwayat al-Bukhârî dengan redaksi:

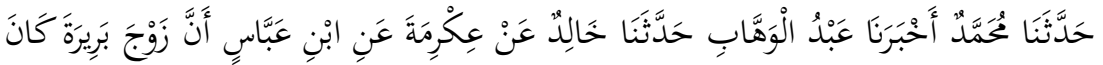

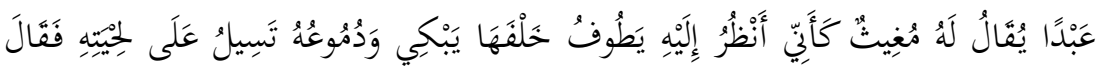

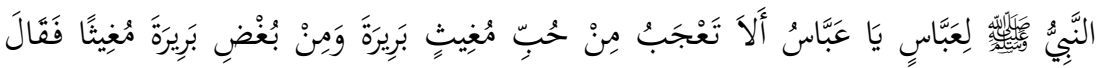

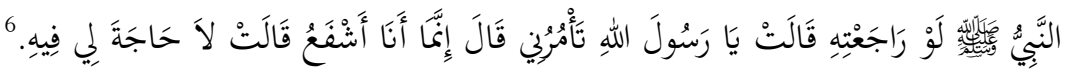

“... dari Ibn 'Abbas: bahwa suami Barirah adalah seorang budak yang bernama Mughith. Sepertinya aku melihat ia bertawaf di belakangnya seraya menangis hingga air matanya membasahi jenggot. Maka Nabi bersabda: "Wahai 'Abbas, tidakkah kamu takjub akan kecintaan Mughith terhadap Barirah dan kebencian Barirah terhadap Mughith?" Akhirnya Nabi pun berkata kepada Barirah: "Seandainya kamu mau merujuknya kembali." Barirah bertanya: "Wahai Rasulullah, apakah Anda menyuruhku?" Beliau menjawab: "Aku hanya menyarankan." Akhirnya Barirah pun berkata: "Sesungguhnya aku tak berhajat sedikit pun padanya."

Keempat adalah hadis riwayat Muslim dengan redaksi:

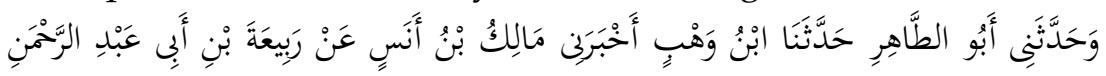

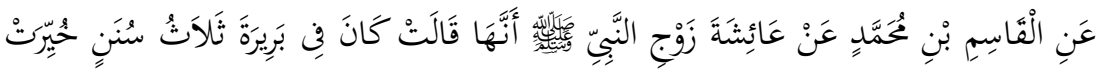

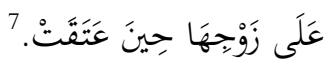

5 al-Bukhârî, al-Jâmı̂‘ al-Shahîh, Vol. 7, 61.

${ }^{6}$ Ibid., 62.

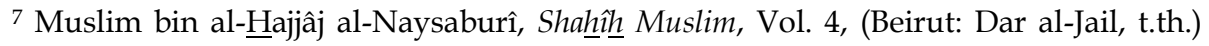
215. 
“... dari 'A'ishah istri Nabi bahwa dia berkata; "Dalam kasus Barirah ada tiga sunnah (salah satu di antaranya) yaitu; dia diberi pilihan atas suaminya ketika dia dibebaskan."

Hadis-hadis di atas mempunyai kandungan makna bahwa seorang perempuan mempunyai kebebasan secara penuh untuk memilih suaminya, tanpa adanya paksaan dari orang tuanya. Bahkan dalam hadis riwayat Ibn Majah disebutkan:

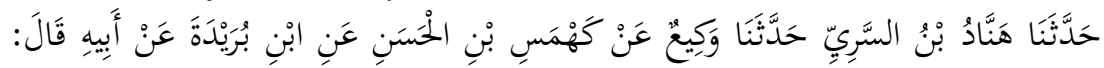

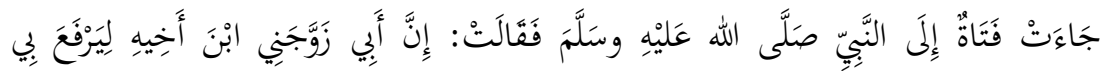

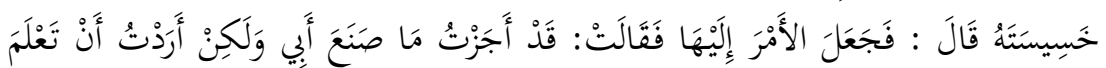

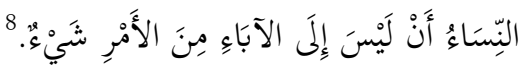

“... dari Ibn Buraydah dari Bapaknya ia berkata; "Ada seorang perawan datang kepada Nabi Saw. dan berkata: "Sesungguhnya bapakku menikahkan aku dengan keponakannya dengan tujuan agar mengangkatnya dari kehinaan." Buraydah berkata: "Maka Beliau menyerahkan urusan itu kepada perawan tersebut." Lalu perawan itu berkata: "Aku telah menerima putusan bapakku, hanya saja aku ingin agar kaum perempuan mengetahui, bahwa para bapak tidak mempunyai keputusan sama sekali dalam masalah ini."

Dalam hadis yang lain disebutkan:

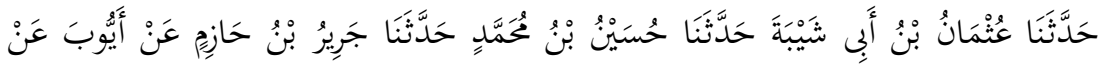

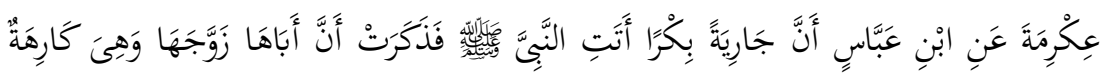

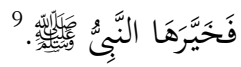

“... dari Ibn 'Abbas, bahwa seorang perawan datang kepada Nabi Saw. dan menyebutkan bahwa bapaknya telah menikahkannya sementara ia tidak senang. Kemudian Nabi memberikan khiyar (pilihan untuk meneruskan pernikahan atau membatalkannya) kepadanya."

Hadis Buraydah di atas secara jelas menegaskan bahwa urusan memilih suami secara penuh merupakan hak seorang perempuan, bukan berdasarkan keputusan, apalagi paksaan dari orang tua. Hal

${ }^{8}$ Ibn Mâjah al-Qazwaynî, Sunan Ibn Mâjah, Vol. 3, (t.t.: Maktabah Abi al-Ma'ati, t.th.), 73.

9 Abû Dawûd al-Sijistânî, Sunan Abî Dawî̀, Vol. 2, (Beirut: Dâr al-Kitâb al-'Arabî, t.th.), 195. 
ini ditegaskan oleh perkataan perempuan pada hadis Buraydah di atas, "bahwa para bapak tidak mempunyai keputusan sama sekali dalam masalah ini." Apa yang diucapkan perempuan pada hadis di atas diketahui oleh Nabi dan dibiarkan. Hal ini menjadi ketetapan (taqrîr) dari Nabi. Perempuan juga berhak menentukan untuk melanjutkan pernikahan atau membatalkannya setelah dinikahkan oleh walinya dengan orang yang tidak dicintainya.

Hak memilih suami bagi seorang perempuan dalam Islam tidak dibedakan antara laki-laki dan perempuan. Persamaan laki-laki dan perempuan dalam masalah ini dapat ditinjau dari persamaan dalam hak dan kewajiban dalam agama. Kedudukan seorang perempuan tidak lebih rendah dari laki-laki, baik dalam akal, kecakapan, maupun kewajiban-kewajiban lain yang bersifat syar'i. Keduanya mempunyai hak dan kewajiban yang sama. Persamaan ini banyak ditunjukkan oleh ayat-ayat berikut ini: 10

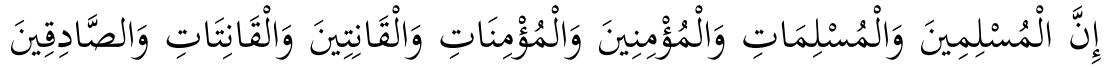

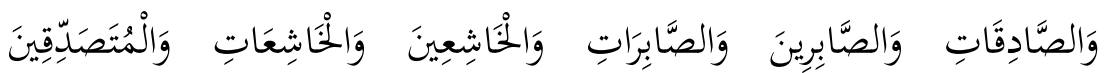

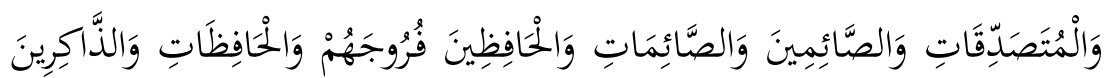

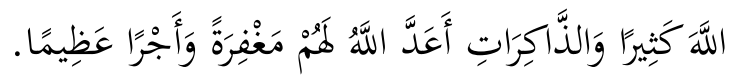

"Sesungguhnya laki-laki dan perempuan yang muslim, laki-laki dan perempuan yang mukmin, laki-laki dan perempuan yang tetap dalam ketaatannya, laki-laki dan perempuan yang benar, laki-laki dan perempuan yang sabar, laki-laki dan perempuan yang khusyuk, laki-laki dan perempuan yang bersedekah, laki-laki dan perempuan yang berpuasa, laki-laki dan perempuan yang memelihara kehormatannya, laki-laki dan perempuan yang banyak menyebut (nama) Allah, Allah telah menyediakan untuk mereka ampunan dan pahala yang besar." [QS. al-Ahzab 33: 35]

$$
\text { كُلُّْ نَفْسِ بِمَا كَسَبَتَتْ رَهِينَةُ. }
$$

"Tiap-tiap individu (baik laki-laki maupun perempuan) bertanggung jawab atas apa yang telah diperbuatnya." [QS. al-Muddatstsir 74: 38]

\footnotetext{
${ }^{10}$ Dalâl Kadzîm 'Ubayd, Mafhûm Hurriyat al-Mar'ah fí Dlaw' al-Fikr al-Tarbawî al-Islâmi,
} (Beirut: Kitâb-Nashirun, 2011), 111. 
نَقِقِيرًا.

"Barangsiapa yang mengerjakan amal-amal saleh, baik laki-laki maupun perempuan sedang ia orang yang beriman, maka mereka itu masuk ke dalam surga dan mereka tidak dianiaya walau sedikitpun." [QS. al-Nisa' 4: 124]

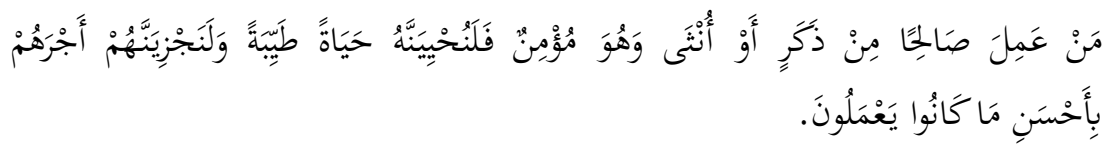

"Barangsiapa yang mengerjakan amal saleh, baik laki-laki maupun perempuan dalam keadaan beriman, maka sesungguhnya akan Kami berikan kepadanya kehidupan yang baik dan sesungguhnya akan Kami beri balasan kepada mereka dengan pahala yang lebih baik dari apa yang telah mereka kerjakan." [QS. al-Nahl 16: 97]

Ayat-ayat di atas menegaskan persamaan antara laki-laki dan perempuan dalam mendapatkan pahala amal saleh. Bila dalam amal saleh kaum perempuan mendapatkan hak yang sama dalam pahala, maka tentunya dalam memilih suami pun mereka mempunyai hak yang sama seperti halnya kaum laki-laki. Mempunyai seorang suami (suami yang saleh tentunya) merupakan salah satu cara bagi kaum perempuan untuk tetap dapat berbakti kepada Allah.

Ibn Taymiyah dalam fatwanya menegaskan bahwa meminta izin kepada perawan yang balighah merupakan sesuatu yang wajib bagi bapak dan wali yang lainnya. Seorang bapak tidak boleh memaksanya untuk menikah. ${ }^{11}$ Ibn Taymiyah juga menegaskan bahwa pendapat yang shahîh, wilayah ijbâr bagi seorang bapak hanya berlaku bagi perempuan yang masih kecil (belum balighah). Adapun perawan yang sudah balighah, maka tak seorang pun dari walinya yang berhak untuk memaksanya. Hal ini berdasarkan hadis Nabi Saw.:

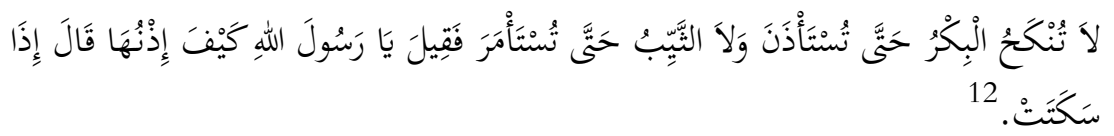

11 Aḥmad bin 'Abd al-Halîm Ibn Taymiyah, Majmî̀' al-Fatâwâ, Vol. 32, (t.t.: Dar alWafa', 2005), 22.

12 Al-Bukhârî, al-Jâmî̀ al-Shahîh, Vol. 9, 32. 
"Perawan tidak boleh dinikahkan hingga dimintai izin, dan janda tidak boleh dinikahkan hingga dimintai persetujuannya." Ada yang bertanya; "Ya Rasulullah, bagaimana tanda izinnya?" Nabi menjawab: "Tandanya diam."

Dalam riwayat yang lain disebutkan:

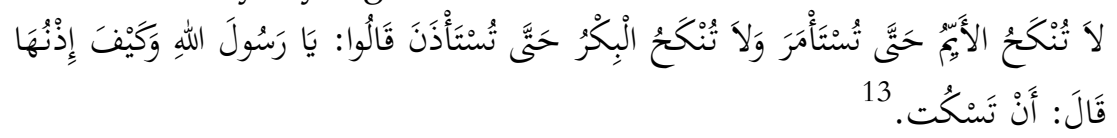

"Seorang janda tidak boleh dinikahkan hingga ia dimintai pendapatnya, sedangkan gadis tidak boleh dinikahkan hingga dimintai izinnya." Para sahabat bertanya: "Wahai Rasulullah, seperti apakah izinnya?" Nabi menjawab: "Bila ia diam tak berkata."

Hadis ini merupakan larangan dari Nabi bagi seorang bapak (wali) untuk menikahkan anaknya yang perawan tanpa izin kepada anak perawan tersebut. ${ }^{14} \mathrm{Hal}$ ini juga ditegaskan oleh al-Bukhârî yang meriwayatkan hadis di atas dengan mencantumkannya pada bab "Bâb La Yunkah al-Ab wa Ghayruh al-Bikr wa al-Thayyib Illa bi Ridlâhâ". Bapak dan wali yang lainnya tidak boleh menikahkan perawan dan janda kecuali atas persetujuan perawan dan janda tersebut. ${ }^{15}$

Ibn Taymiyah juga mengemukakan alasan lain bahwa seorang bapak tidak boleh menggunakan harta anak perempuannya yang balighah kecuali atas izinnya. Jika hartanya saja tidak boleh -dan bapak harus meminta izin terlebih dahulu kepada anak perempuannya ketika ingin menggunakannya-, maka tentunya bud'nya lebih mulia daripada harta bendanya. Lalu bagaimana boleh seorang bapak mentasarufkan bud' tersebut sedangkan anak perempuannya tidak menyukainya? ${ }^{16}$

Al-Syawkânî ketika mengomentari hadis di atas mengatakan bahwa hadis-hadis tersebut secara jelas menyatakan bahwa seorang perawan yang balighah apabila dinikahkan tanpa izinnya, maka akad nikah tersebut tidak sah. ${ }^{17} \mathrm{Hal}$ ini sebenarnya juga telah ditegaskan oleh al-Bukhârî dalam kitab Sahihnya ketika ia membuat sebuah bab

${ }^{13}$ Ibid., Vol. 7, 23.

${ }^{14}$ Ibn Taymiyah, Majmu' al-Fatawa, 23.

${ }^{15}$ Al-Bukhârî, , al-Jâmi' al-Shahîh, Vol. 7, 23.

${ }^{16}$ Ibn Taymiyah, Majmu' al-Fatawa, 23.

${ }^{17}$ Muhammad bin 'Alî al-Syawkânî, Nayl al-Awthâr min Ahâdîts Sayyid al-Akhyâr Syarh Muntaqî al-Akhbâr, Vol. 6 (t.t.: Idârah al-Thibâ'ah al-Munîriyah, t.th.), 183. 
yang berjudul "Bâb Idzâ Zawwaja Ibnatah wa Hiya Kârihah fa Nikahuh Mardûd". Ketika seorang wali menikahkan anak perempuannya sedangkan anak perempuan tersebut tidak suka (benci), maka nikahnya tertolak (batal).18 Al-Bukhârî tidak membedakan antara perawan dan janda. Dalam judul tersebut ia menggunakan kata "Ibnat" yang bermakna anak perempuan secara umum, tidak terbatas pada perawan ataupun janda. ${ }^{19}$

Al-Qardlâwî ketika mengomentari hadis Ibn Mâjah di atas (Aku telah menerima putusan bapakku, hanya saja aku ingin agar kaum perempuan mengetahui, bahwa para bapak tidak mempunyai keputusan sama sekali dalam masalah ini) berkata: "Seolah-olah perempuan ini ingin menyadarkan perempuan-perempuan lain terhadap hak yang telah diberikan oleh al-Syari' kepada diri mereka, sehingga hak tersebut tidak dirampas oleh para bapak atau wali-wali lain di bawah bapak yang menikahkan mereka tanpa keridhaan mereka dengan orang yang dibenci oleh mereka."20

Dapat disimpulkan bahwa memilih suami merupakan hak yang diberikan oleh Syara' kepada seorang perempuan secara mutlak. Seorang bapak ataupun wali yang lain yang merampas hak itu dengan cara memaksa menikahkan anak perempuan dengan laki-laki yang tidak dicintainya, maka hal itu merupakan pelanggaran. Tentang hal ini, mufti al-Azhar, 'Athiyyah Saqr mengatakan:

\footnotetext{
18 Al-Bukhârî, al-Jami' al-Shahih, Vol. 7, 23.

${ }^{19}$ Menurut 'Abd al-Rahmân al-Jazîrî, al-bikr (perawan) adalah istilah bagi perempuan yang sama sekali belum pernah dijima' (digauli). Perempuan seperti ini disebut bikr secara hakiki. Perempuan yang hilang keperawanannya karena terjatuh, haid yang terlalu kuat atau karena operasi juga disebut perawan secara hakiki. Demikian juga perempuan yang menikah dengan akad yang sah atau akad yang fâsid, akan tetapi ia dicerai oleh suaminya atau suaminya mati sebelum perempuan tersebut digauli, atau perempuan tersebut dipisahkan oleh qadi karena suaminya impoten atau majbub (zakarnya putus), maka perempuan-perempuan ini juga disebut bikr secara hakiki. Adapun perempuan yang hilang keperawanannya karena zina, maka ia disebut bikr secara hukum (bikr hukmi), maksudnya ia dianggap bikr, meskipun keperawanannya telah hilang dengan catatan zinanya tidak berulang dan ia tidak dihad (dihukum cambuk). Jika ia melakukan zina berulang kali atau ia terkena had, maka ia disebut dengan al-tsayyib (janda). Dengan demikian, maka al-tsayyib (janda) adalah perempuan yang digauli dengan nikah yang sah, nikah yang fâsid, wath'i shubhat, zina yang dihad meskipun sekali atau zina yang berulang meskipun tidak dihad. ("Abd alRahmân al-Jazîrî, al-Fiqh 'alâ al-Madzâhib al-'Arba'ah, Vol. 4, (t.t.: t.p., t.th.), 32.)

${ }^{20}$ Yûsuf al-Qardlâwî, Fatâwâ al-Mu'âshirah, Vol. 2, (t.t.: t.p., t.th.), 315.
} 


$$
\text { وإن استبداد الولى باختيار الزوج وانفراده بالعقد هو جناية على المرأة واستهانة بعواطفها }
$$

"Sesungguhnya kesewenang-wenangan wali dalam memilihkan suami (untuk anak perempuannya) dan menikahkannya merupakan kejahatan terhadap perempuan dan merendahkan kasih sayang dan perasaannya."

Pandangan 'Athiyyah merupakan sesuatu yang beralasan, karena Rasulullah sendiri telah bersabda:

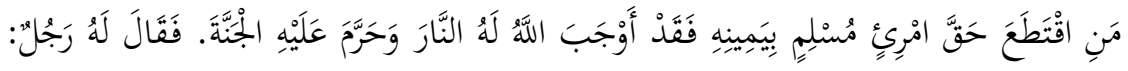

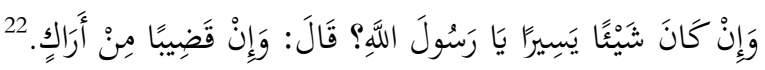

"Barangsiapa mengambil hak seorang muslim dengan sumpahnya, maka Allah mewajibkan neraka untuknya dan mengharamkan surga atasnya." Seorang laki-laki bertanya: "Wahai Rasulullah, meskipun itu sesuatu yang sepele?" Beliau menjawab: "Meskipun itu hanya kayu siwak."

Jika merampas sepotong kayu siwak saja mendapat ancaman dari Allah dan Rasul-Nya, lalu bagaimana jika yang dirampas adalah hak memilih suami yang diberikan oleh al-Syari' kepada perempuan? Allah telah memberikan hak setiap orang yang mempunyai hak ${ }^{23}$ dan Rasulullah juga telah memerintahkan umatnya untuk memberikan setiap hak bagi orang yang mempunyai hak. ${ }^{24}$

\section{Peranan Wali dalam Pernikahan}

Keberadaan wali dalam akad nikah merupakan sebuah rukun yang harus terpenuhi menurut mayoritas ulama Malikiyyah,

21'Athiyyah Saqr, Fatâwâa al-Azhar, Vol. 9, (t.t.: Mawqi' Wizârah al-Awqâf alMishriyyah, t.th.), 464.

22 Muslim, Shahîh Muslim, Vol. 1, (Beirut: Dâr al-Jayl, t.th.) 85.

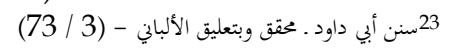

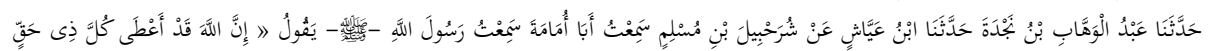

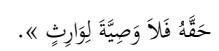

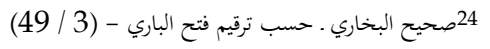

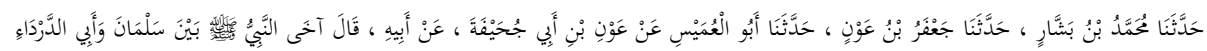

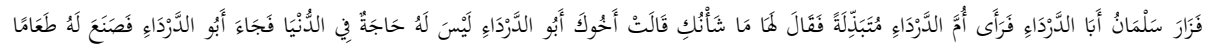

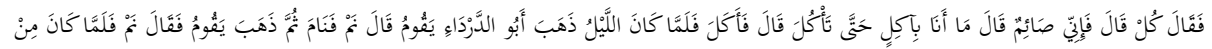

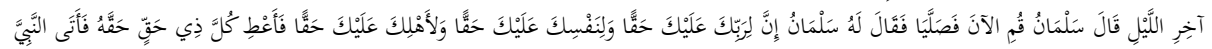
界 
Syafi'iyyah, dan Hanabilah. ${ }^{25}$ Kelompok ini berargumen dengan ayat al-Qur' an dan hadis. Salah satu hadis yang dipakai oleh kelompok ini adalah hadis riwayat ' $\mathrm{A}$ ' isyah sebagai berikut:

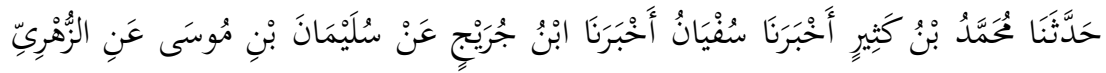

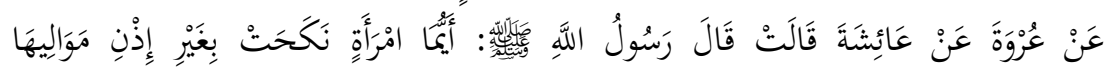

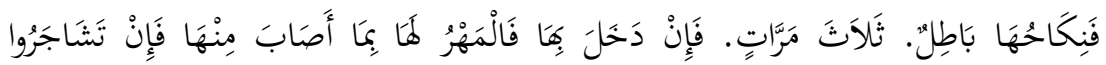

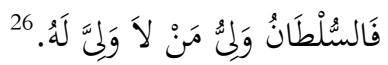

“...dari 'A'isyah, ia berkata; Rasulullah Saw. bersabda: "Setiap wanita yang menikah tanpa seizin walinya, maka pernikahannya adalah batal." Beliau mengucapkannya sebanyak tiga kali. Apabila ia telah mencampurinya maka baginya mahar karena apa yang ia peroleh darinya, kemudian apabila mereka berselisih maka penguasa adalah wali bagi orang yang tidak memiliki wali."

Implikasi hukum dari hadis ini adalah akad nikah yang dilangsungkan tanpa melibatkan seorang wali dari perempuan itu, maka pernikahannya batal (tidak sah). Dengan demikian posisi wali menjadi bagian yang tidak dapat dipisahkan dalam sebuah proses akad nikah.

Pandangan ini berbeda dengan pendapat Hanafiyyah yang tidak menyaratkan keberadaan wali sebagai rukun dalam akad nikah. ${ }^{27}$ Kelompok ini berargumen bahwa setiap orang yang boleh me-tasarrufkan (menggunakan) harta bendanya dengan wilayah (kekuasaan) yang ia miliki, maka ia dapat menikahkan dirinya sendiri, demikian juga sebaliknya. ${ }^{28}$ Adapun hadis yang dijadikan sebagai hujjah mayoritas ulama atas keterlibatan (keharusan) wali dalam akad nikah, yaitu hadis riwayat al-Tirmidzi "Setiap wanita yang menikah tanpa seizin walinya, maka pernikahannya batal." Juga hadis riwayat Abi Dawud "Tidak ada pernikahan (tidak sah) kecuali

${ }^{25}$ Lihat al-Sayyid Sâbiq, Fiqh al-Sunnah, Vol. 2, (Beirut: Dâr al-Ma'rifah, 2010), 359-363. Namun demikian Abû Hanîfah dan Abû Yûsuf berpendapat bahwa seorang perempuan yang berakal dan balighah mempunyai hak untuk melangsungkan akad nikahnya untuk dirinya sendiri.

${ }^{26}$ Abu Dawud, Sunan Abi Dawûd, Vol. 2, (Beirut: Dâr al-Kitâb al-'Arabî, t.th.), 190.

27 Lihat lebih detail argumen Hanafiyyah dalam Ibn Najîm al-Mishrî, al-Bahr r al-Rấ'iq, Vol. 3, (Beirut: Dâr al-Ma'rifah, t.th.), 117. Muhammad bin Abî Sahl al-Sarkhâsî, alMabsûth, Vol. 5, (Beirut: Dâr al-Fikr, 2000), 19. Dan Ibn 'Âbidîn, Hâashiyah Radd alMukhtâr, Vol. 3, (Beirut: Dâr al-Fikr, 2000), 55.

${ }^{28}$ Ibn Najîm al-Mishrî, al-Bahr al-Râ'iq, Vol. 3, (Beirut: Dâr al-Ma'rifah, t.th.), 117. 
dengan wali." Menurut kelompok ini, kedua hadis tersebut dinilai sebagai hadis yang lemah atau setidaknya diperselisihkan kesahihannya. Dengan demikian:

1. Dua hadis di atas tidak bisa dipertentangkan dengan hadis yang telah disepakati kesahihannya, yaitu hadis riwayat Muslim yang berbunyi:

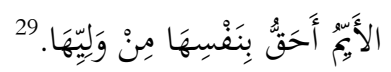

"Al-Ayyim (perempuan yang tidak mempunyai suami, baik perawan maupun janda) lebih berhak atas dirinya daripada walinya."

Al-Ayyim menurut ulama $\mathrm{H}$ \{anafiyyah didefinisikan sebagai perempuan yang tidak mempunyai suami, baik perawan maupun janda. ${ }^{30}$ Definisi semacam ini senada dengan definisi yang diungkapan dalam beberapa kamus, seperti Lisân al-'Arab karya Ibn al-Mandhûr, ${ }^{31}$ al-Qâmûs al-Muhîth karya Muhammad bin Ya'qûb al-Fayrûz Abâdî ${ }^{32}$ dan Tâj al-'Arûs karya Murtadlâ alZabîdî. ${ }^{33}$ Definisi semacam ini tentunya berbeda dengan definisi yang disampaikan oleh ulama Syâfi'iyyah misalnya, dimana mereka mendefinisikan al-ayyim sebagai janda. ${ }^{34}$

2. Hadis "Setiap wanita yang menikah tanpa seizin walinya, maka pernikahannya adalah batal." menurut Hanafiyyah diarahkan kepada budak perempuan, anak kecil atau perempuan yang kurang waras pikirannya. Adapun hadis "Tidak ada pernikahan (tidak sah) kecuali dengan wali." diarahkan sebagai pernikahan yang sempurna, maksudnya tidak ada pernikahan yang sempurna kecuali dengan wali. ${ }^{35}$

Kendati Abû Hanîfah dan Abû Yûsuf berpendapat bahwa seorang perempuan (perawan maupun janda) berakal dan balighah

${ }^{29}$ Muslim, Sahih Muslim, vol. 4 (Beirut: Dar al-Jail, t.th.) 141.

30 Ibn Najîm, al-Bahr al-Râ'iq, Vol. 3, (Beirut: Dâr al-Ma'rifah, t.th.), 117.

31 Ibn al-Mandlûr al-Afrîqî, Lisân al-'Arab, Vol. 12, (Beirut: Dâr Shâdir, t.th.), 39.

32 Muhammad bin Ya'qûb al-Fayrûz Abâdî, al-Qâmûs al-Muhîth, Vol. 1, (t.t.: t.p., t.th.), 1393.

${ }^{33}$ Murtadlâ al-Zabîdî, Tâj al-'Arûs, Vol. 31, (t.t.; Dâr al-Hidâyah, t.th.), 255.

34 Ibn Najîm, al-Bahr al-Rấ'iq, Vol. 3, (Beirut: Dâr al-Ma'rifah, t.th.), 117. Lihat juga Musthafâ Alkhin, Mushthafâ al-Bughâ dan 'Alî al-Sarbajî, al-Fiqh al-Manhajî 'alâ alMadzhab al-Imâm al-Syâfi'î, Vol. 2, (Surabaya: al-Fithrah, t.th.), 62.

35 Ibn Najîm, al-Bahr al-Râ'iq, Vol. 3, 117. 
mempunyai hak dalam melaksanakan akad nikahnya, namun tetap saja dianjurkan baginya untuk memasrahkan akad nikahnya kepada walinya. ${ }^{36}$ Menurut Abû Hanîfah dan Abû Yûsuf seorang wali tidak mempunyai hak untuk menentang keputusan anak perempuannya dalam pernikahan, kecuali si perempuan itu menikahkan dirinya dengan laki-laki yang tidak sekufu atau mahar yang diberikan kepada perempuan itu di bawah mahr al-mithl (di bawah mahar standar). ${ }^{37}$

Artinya apabila perempuan itu memaksakan dirinya menikah dengan laki-laki yang tidak sekufu dan tanpa persetujuan dari walinya, maka pernikahannya tidak sah. Alasannya karena tidak semua wali dapat mengangkat permasalahan itu ke ranah hukum dan tidak semua hakim memutuskan dengan adil terkait masalah itu. Dengan demikian ulama Hanafiyyah berfatwa bahwa pernikahan perempuan itu tidaklah sah. Fatwa semacam ini karena semata-mata untuk menutup pintu pertikaian antara wali dengan perempuan itu maupun dengan suaminya.

Dalam riwayat yang lain disebutkan bahwa seorang wali mempunyai hak untuk menentang, yakni dengan mengajukan gugatan kepada hakim agar hakim membatalkan pernikahan itu, karena untuk menghindari aib yang akan diterima oleh perempuan dan walinya, dengan catatan perempuan tersebut belum mengandung atau melahirkan anak dari laki-laki yang menikahinya itu. Jika perempuan itu telah mengandung atau bahkan telah melahirkan anak dari laki-laki tersebut, maka hak wali untuk mengajukan gugatan kepada hakim agar memisahkan keduanya telah gugur. Alasannya karena demi menjaga hak anak dan kandungan agar tidak tersia-siakan. Apabila perempuan itu menikah dengan lakilaki yang sekufu, namun mahar yang diberikan dibawah mahr al-mithl (mahar di bawah standar), maka wali mempunyai hak menuntut lakilaki tersebut agar memberikan mahar yang standar. Jika laki-laki itu menolak, maka wali boleh mengajukan gugatan ini kepada hakim agar hakim membatalkan akad nikahnya. ${ }^{38}$

Meskipun ulama Hanafiyyah berpendapat bahwa wali bukan merupakan rukun dalam akad nikah, namun perannya tidak bisa

\footnotetext{
36 Sayyid Sâbiq, Fiqh al-Sunnah, 361-362.

37 Ibid.

38 Ibid.
} 
dikesampingkan. Seorang perempuan dianjurkan untuk menyerahkan akad nikahnya kepada walinya. Wali pun dalam hal ini mempunyai hak-hak yang tidak bisa diabaikan.

\section{Seorang Bapak Menikahkan Anak Perempuannya Tanpa Izin Darinya}

Dalam kitabnya al-Jâmi' al-Shahîh, Muslim menulis bab yang berjudul "Bâb Tazwî̀ al-Ab al-Bikr al-Shaghîrah", bab menjelaskan tentang kebolehan seorang bapak menikahkan anak perawannya yang masih kecil. Kemudian Imam Muslim menampilkan hadis sebagai berikut:

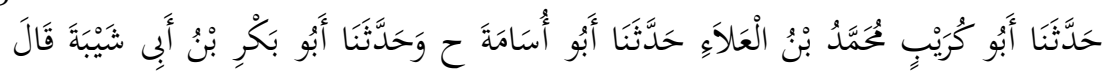

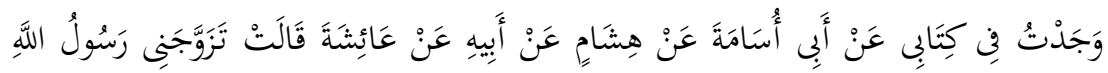

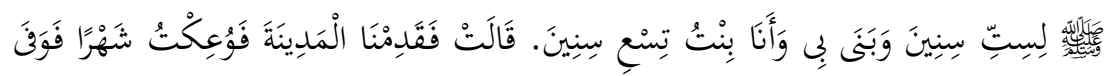

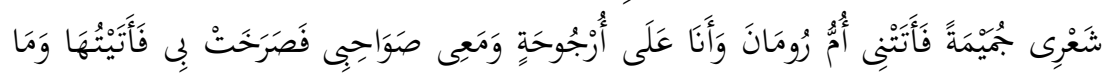

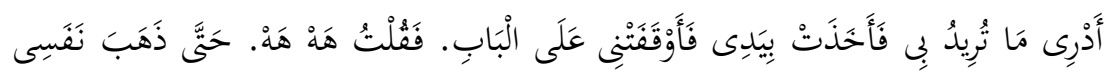

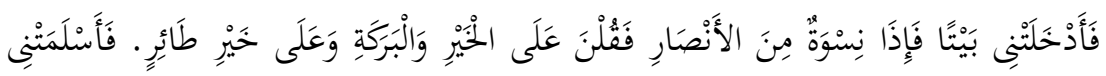

$$
\begin{aligned}
& 39 .
\end{aligned}
$$

“... dari 'A'isyah berkata: "Rasulullah menikahiku waktu aku berumur enam tahun, dan memboyongku (membina rumah tangga denganku) ketika aku berusia sembilan tahun." 'A'isyah berkata; "Sesampainya di Madinah, aku jatuh sakit selama sebulan, hingga rambutku rontok. Setelah sembuh, Ummu Rûmân mendatangiku, ketika itu aku sedang bermain-main bersama kawankawanku, lantas dia memanggilku, dan aku mendatanginya, namun aku tidak tahu apa yang dia inginkan dariku. Kemudian dia memegang tanganku dan membawaku sampai ke pintu rumah, (aku terengah-engah) sambil menarik nafas; hah...hah... sehingga nafasku lega kembali. Kemudian aku dibawa masuk ke dalam rumah, tiba-tiba di sana telah menunggu beberapa wanita Ansar. Mereka mengucapkan selamat dan kebaikan kepadaku, lantas Ummu Ruman menyerahkanku kepada mereka, akhirnya mereka membersihkan kepalaku dan mendandaniku, pada waktu dluha, betapa terkejutnya aku ketika melihat Rasulullah muncul di tempat kami, kemudian mereka menyerahkanku kepada beliau."

${ }^{39}$ Muslim, Shahîh Muslim, Vol. 4, (Beirut: Dâr al-Jayl, t.th.) 141. 
Ketika mengomentari hadis ini, al-Nawawî berkata:

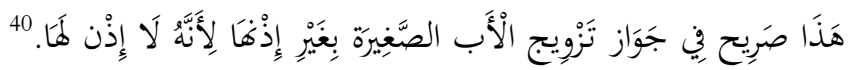

"Hadis ini secara jelas menunjukkan kebolehan seorang bapak menikahkan anak perempuannya yang masih kecil tanpa izinnya, karena ia belum mempunyai izin."

Al-Nawawî juga berkata:

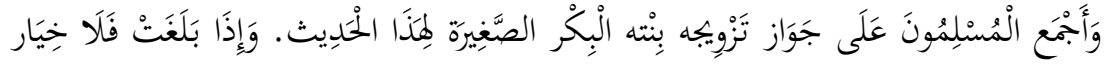

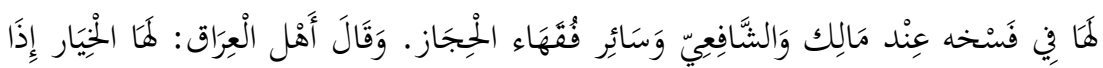

$$
\begin{aligned}
& \text { بَلَغَتْنْ. }
\end{aligned}
$$

"Kaum muslimin sepakat atas kebolehan bapak menikahkan anak perawannya yang masih kecil berdasarkan hadis ini. Ketika ia sudah balighah, maka ia tidak mempunyai pilihan untuk membatalkan pernikahannya menurut pendapat Mâlik, al-Syâfi'î dan semua ulama Hijâz. Namun ulama Irak berpendapat, ia mempunyai hak khiyâr (memilih untuk melangsungkan atau membatalkan pernikahannya) ketika sudah balighah."

Nampaknya -menurut penulis- pendapat ulama Irak yang memperbolehkan khiyâr lebih kuat ditinjau dari segi dalil, karena seorang perempuan yang sudah bâlighah mempunyai hak untuk membatalkan pernikahannya jika alasannya dibenarkan oleh agama. Hal ini sebagaimana keterangan dalam hadis berikut ini:

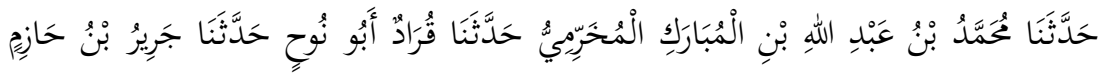

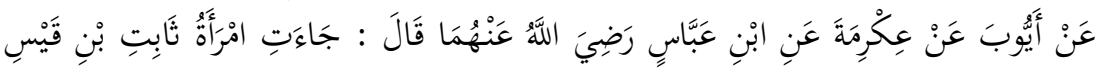

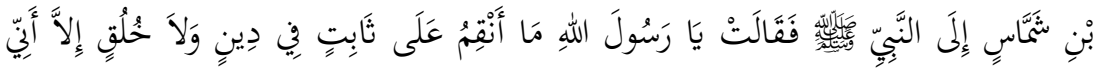

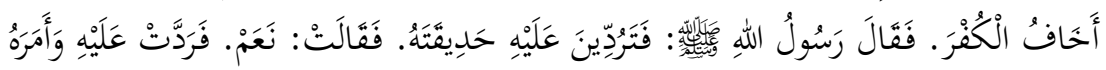

$$
\begin{aligned}
& \text { فَفَفَارَقَهَا. }
\end{aligned}
$$

“... dari Ibn 'Abbas, ia berkata: "Suatu ketika, isteri Thabit bin Qays bin Shammas datang kepada Nabi Saw. dan berkata: "Wahai Rasulullah, tidaklah aku mencela Tsabit atas agama ataupun akhlaknya, akan tetapi aku khawatir terjerumus dalam kekufuran." Maka Rasulullah bersabda: "Kalau begitu,

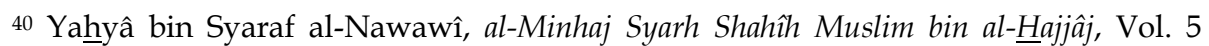
(Beirut: Dâr Ihyâ' al-Turâts al-'Arabî, 1392 H.), 128.

41 Ibid.

42 Al-Bukhârî, al-Jami' al-Shahih, Vol. 7, 60. 
kembalikanlah kebun miliknya." Perempuan itu berkata: "Ya." Maka ia pun mengembalikan kebun itu pada Tsabit, lalu Rasulullah memerintahkan Tsabit agar mengambil kebun itu, kemudian Tsabit menceraikan perempuan itu."

Dalil lain yang digunakan oleh sebagian ulama tentang kebolehan seorang bapak menikahkan anak perawannya tanpa izinnya ${ }^{43}$ adalah hadis:

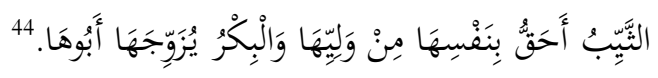

"Janda lebih berhak terhadap dirinya daripada walinya dan perawan bapaknya yang menikahkannya."

Di kalangan Mazhab Syâfi'î, kebolehan menikahkan anak perawan (baik yang masih kecil atau yang bâlighah) tanpa sepengetahuan si anak hanya tertentu pada wali mujbir. Yaitu wali yang boleh memaksa anak perempuannya yang masih perawan untuk dinikahkan pada orang lain (wali mujbir hanya terbatas pada ayah dan kakek). ${ }^{45}$ Hal ini berdasarkan pada sebuah hadis yang diriwayatkan oleh Ibn 'Abbas, bahwa Rasulullah bersabda: "Janda lebih berhak terhadap dirinya daripada walinya (dalam nikah) dan perawan bapaknya dianjurkan untuk minta persetujuannya." Dalam riwayat lain: "Perawan bapaknya yang menikahkannya." 46

Namun kebolehan seorang wali mujbir menikahkan anak perawannya tanpa sepengetahuan si anak harus memenuhi syaratsyarat berikut:

1. Tidak ada permusuhan antara wali dan anak perempuan secara.

\footnotetext{
43أسنى المطالب في شرح روض الطالب - (3 / 127)

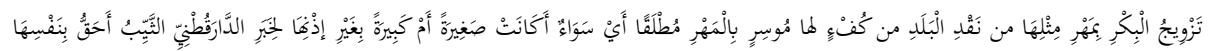

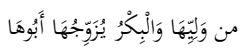

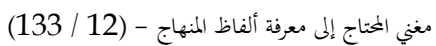

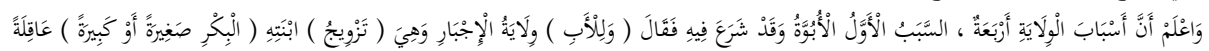

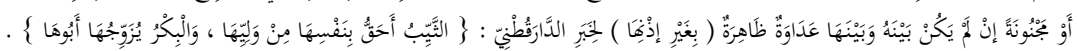

44 Ahmad bin al-Husayn al-Bayhaqî, al-Sunan al-Kubrâ, Vol. 7 (Hydar Abâd: Majlis Dâ'irah al-Ma'ârif al-Nidhâmiyah al-Kâ'inah, 1344 H.), 115.

45 Menurut madzhab Hanafî, hak ijbâr yang dimiliki oleh wali mujbir hanya berlaku pada anak yang masih kecil (belum baligh), baik laki-laki maupun perempuan dan anak yang gila, laki-laki maupun perempuan. 'Abd al-Rahmân al-Jazîrî, al-Figh 'alâ alMadzâhib al-Arba'ah, Vol. 4 (t.t.: t.tp, t.th.), 24

46Ibid.
} 
2. Antara anak perempuan dan calon suaminya tidak ada permusuhan secara dhahir dan batin. Dengan demikian, jika wali menikahkan anak perempuannya dengan seorang laki-laki yang dibenci oleh anak perempuannya, atau wali menghendaki kejelekan, maka nikahnya tidak sah.

3. Calon suaminya sekufu

4. Calon suaminya mampu membayar mas kawin.

Keempat syarat ini harus terpenuhi semuanya agar akad nikahnya sah. Konsekuensinya, apabila terjadi akad nikah dan salah satu syarat yang empat ini tidak terpenuhi, maka nikahnya tidak sah dengan catatan si anak perempuan tidak ridha dengan akad nikah ini.

5. Wali menikahkan anak perempuannya dengan mah\}r mithl (mahar pada umumnya yang berlaku pada suatu daerah)

6. Mahar berasal dari naqd al-balad (mata uang suatu negara)

7. Mahar harus kontan. ${ }^{47}$

Para ulama yang berargumen dengan hadis di atas ("Perawan bapaknya yang menikahkannya") menisbatkan riwayat tersebut kepada al-Dâruquthnî. ${ }^{48}$ Namun setelah penulis melacak di kitab Sunan alDâruqutnî dengan mesin pencari hadis al-Maktabah al-Syâmilah, penulis tidak menemukan hadis tersebut. Dalam Sunan al-Dâruqutnî hanya terdapat redaksi hadis berikut:

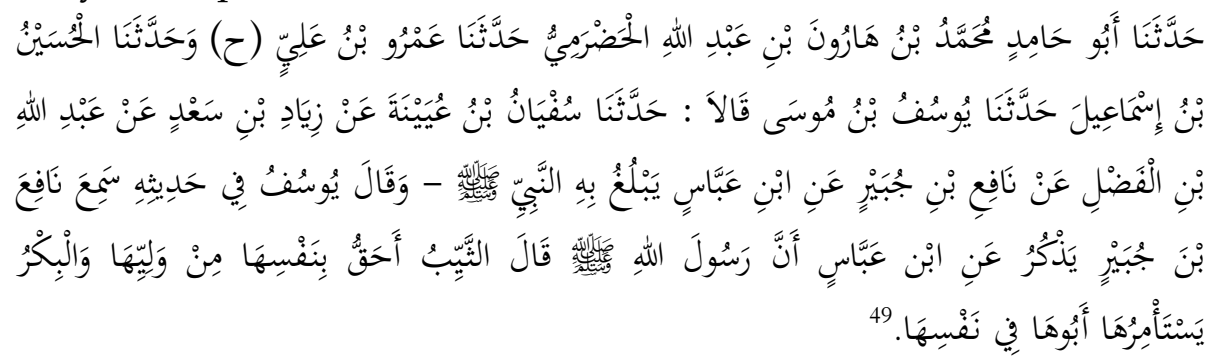

Al-Hâfidh Ibn Hajar yang mentakhrîj hadis tersebut dalam

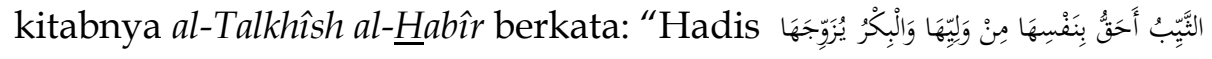
أَبْوًَا, 'Janda lebih berhak terhadap dirinya daripada walinya dan

47 Ibid., 21.

48 Lihat catatan kaki no. 45

49 'Alî bin 'Umar al-Dâruquthnî, Sunan al-Dâruquthnî, Vol. 4, (t.t.: Mu'assasah alRisâlah, t.th.), 349. 
perawan bapaknya yang menikahkannya.' merupakan hadis yang diriwayatkan al-Dâruquthnî dari hadis Ibn 'Abbâs dengan redaksi ini,

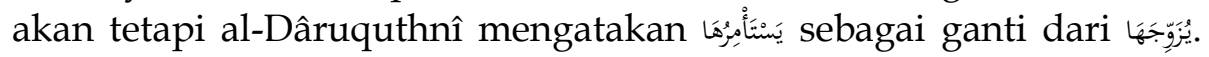
Al-Bayhaqî mengisahkan dari al-Syâfi'î bahwa Ibn 'Uyaynah

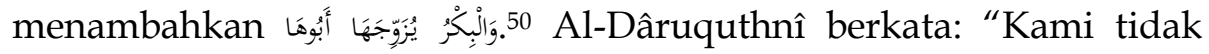
mengetahui seorang pun yang menyamai Ibn 'Uyaynah dalam riwayat itu. Hadis tersebut dalam Shahîh Muslim menggunakan

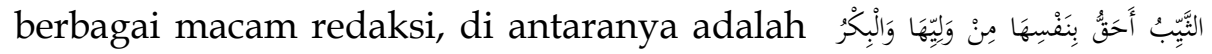

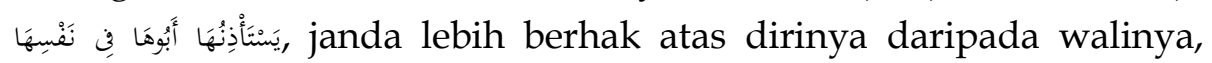
sedangkan perawan, maka bapaknya harus meminta persetujuannya pada dirinya." 51

Dari data yang disampaikan oleh Ibn Hajar ini, maka dapat

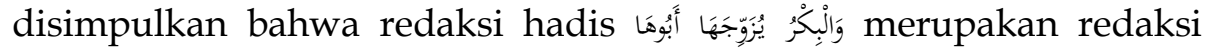
tambahan yang diriwayatkan oleh Ibn 'Uyaynah. Dengan demikian tambahan redaksi yang disampaikan oleh Ibn 'Uyaynah tersebut merupakan kategori ziyâdât al-tsiqâh, karena Ibn 'Uyaynah merupakan rawi yang siqah $^{52}$.

Ziyâdât al-tsiqât adalah tambahan redaksi hadis yang diriwayatkan oleh seorang rawi yang tsiqah yang tidak diriwayatkan oleh para perawi thiqah yang lain. ${ }^{53}$ Menurut Ibn Shalâh hukum Ziyâdât al-tsiqât terbagi menjadi tiga:

1. Tambahan yang tidak bertentangan dengan hadis yang diriwayatkan oleh para perawi tsiqah yang lain. Hukum ziyâdât al-tsiqât semacam ini adalah maqbûl (diterima).

2. Tambahan yang bertentangan dengan hadis yang diriwayatkan oleh para perawi thiqah yang lain. Hukum ziyâdât al-tsiqât semacam ini adalah mardîd (tertolak).

3. Tambahan yang di dalamnya terdapat sesuatu yang menafikan terhadap hadis yang diriwayatkan oleh para perawi thiqah yang lain. Tentang hukum yang ketiga ini Ibn Shalâh tidak

\footnotetext{
50 al-Bayhaqî, al-Sunan al-Kubrâ, Vol. 7, 115.

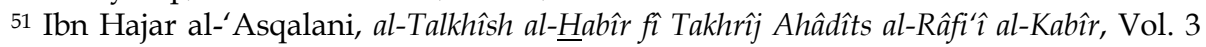
(Beirut: Dâr al-Kutub al-'Ilmiyah, 1989), 348-349.

52 Muhammad bin Aḥmad al-Dhahabî, Siyar A'lâm al-Nubalâ', Vol. 8 (t.t.: Mu'assasah al-Risâlah, 1985), 454.

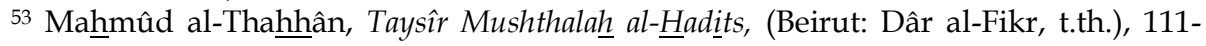
112.
} 
berkomentar. Namun menurut al-Nawawî, jenis yang ketiga ini menurut pendapat yang sahîh diterima. Menurut Mahmûd alThahhân, jenis yang ketiga ini diterima oleh Madzhab Syâfi'î dan Mâliki, namun ditolak oleh Madzhab $\underline{\text { Hanafî. }}$.

Terkait dengan tambahan yang disampaikan Ibn 'Uyaynah, jika melihat pada pernyataan al-Dâruquthnî yang mengatakan: "Kami tidak mengetahui seorang pun yang menyamai Ibn 'Uyaynah dalam riwayat itu.", maka tambahan Ibn 'Uyaynah ini termasuk dalam kategori hadis syâdz yang hukumnya tertolak, karena bertentangan dengan riwayat-riwayat lain. Ibn Hajar sendiri setelah mentakhrîj hadis tersebut mengatakan bahwa hadis tersebut bertentangan dengan riwayat Ibn 'Abbâs yang berbunyi:

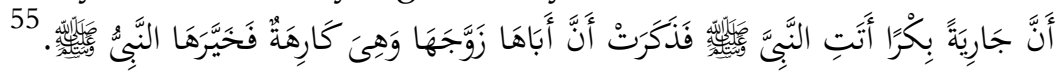

"Bahwa seorang perawan datang kepada Nabi Saw. dan menyebutkan bahwa bapaknya telah menikahkannya sementara ia tidak senang. Kemudian Nabi Saw. memberikan khiyar (pilihan untuk meneruskan pernikahan atau membatalkannya) kepadanya."

Menurut Ibn Hajar, para perawi hadis ini adalah para perawi yang tsiqah. 56 Seandainya tambahan riwayat Ibn 'Uyaynah dikatakan sahih, maka maknanya harus diarahkan bahwa yang dikehendaki adalah kebolehan bagi seorang bapak menikahkan anak perawannya tanpa izinnya pada anak perawan yang belum balighah, sebagaimana hadis 'A'isyah di atas. Jika tidak demikian, maka hadis itu akan bertentangan dengan hadis-hadis yang telah disebutkan di atas.

\section{Penolakan Anak Kepada Orang Tua Ketika Tidak Mau Dinikahkan Dengan Orang Yang Tidak Disukainya} disebutkan:

Dalam sebuah hadis riwayat al-Bukhârî dan Muslim

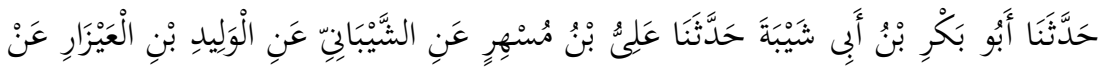

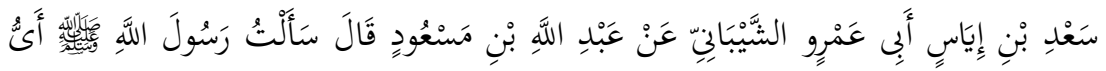

54 Ibid., 112-113.

55 Abû Dawûd al-Sijistânî, Sunan Abî Dawûd, Vol. 2, (Beirut: Dâr al-Kitâb al-'Arabî, t.th.), 195.

56 Ibn ㅂajar al-'Asqalânî, al-Talkhîsh al-Habîr, 349. 


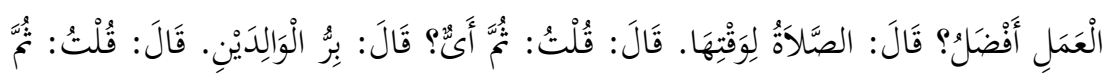

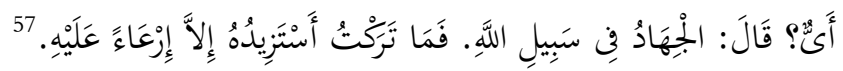

“... dari 'Abdullah bin Mas'ud dia berkata: "Saya bertanya kepada Rasulullah Saw., amal apakah yang paling utama?" Beliau menjawab: "Shalat pada waktunya." Aku bertanya lagi: "Kemudian apa lagi?" Beliau menjawab: "Berbakti kepada kedua orang tua." Aku bertanya lagi: "Kemudian apa lagi?" Beliau menjawab: "Berjuang di jalan Allah." Kemudian aku tidak menambah pertanyaan lagi karena semata-mata menjaga perasaan beliau."

Ketika mengomentari hadis ini, al-Marâghî berkata:

$$
\text { والمراد ببرهما احترامهما احترام المحبة والكرامة لا احترام الخوف والرهبة. } 58
$$

"Yang dimaksud dengan berbakti kepada kedua orang tua adalah menghormati keduanya dengan penghormatan yang dilandasi cinta kasih dan kemuliaan, bukan menghormati karena rasa takut."

Dengan denikian, menurut al-Marâghî, kedua orang tua tidak boleh menghukumi urusan anak yang bersifat khusus, lebih-lebih orang tua tidak boleh menikahkan anaknya dengan orang yang tidak dicintainya atau melarangnya hijrah untuk menuntut ilmu yang bermanfaat, mencari harta, kedudukan dan lain sebagainya. ${ }^{99}$

Muhammad bin Shâlih al-'Utsaymin menjelaskan bahwa berbakti kepada kedua orang tua adalah berbuat baik kepada keduanya dengan harta, badan, kedudukan termasuk juga dengan ucapan dan perbuatan. Berbakti kepada kedua orang tua juga dilakukan dengan melayani keduanya secara baik sesuai dengan kebiasaan yang berlaku. Namun ketika orang tua menyuruh anak untuk melakukan sesuatu yang haram, maka seorang anak tidak boleh menurutinya. Dalam kasus seperti ini mencegah orang tua melakukan sesuatu yang haram merupakan bagian dari berbakti kepada kedua orang tua. Hal ini berdasarkan sabda Nabi Saw.:

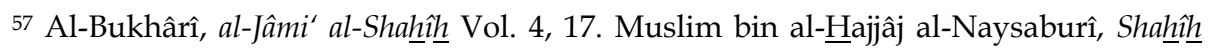
Muslim, Vol. 1, 62. Redaksi hadis di atas menggunakan riwayat Muslim.

58 Ahmad Musthafâ al-Marâghî, Tafsîr al-Marâghî, Vol. 8, (Mesir: Syirkah Maktabah wa Mathba'ah Mushthafâ al-Bâbî al-Halibî wa Awlâdih, t.th.), 67.

59 Ibid.
} 


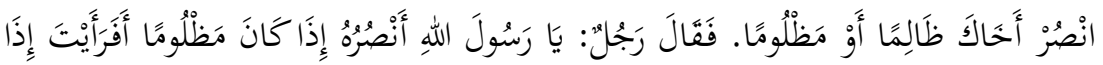

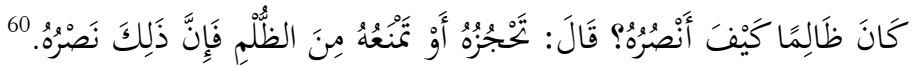

"Tolonglah saudaramu baik ia zalim atau dizalimi." Ada seorang laki-laki bertanya: "Ya Rasulullah, saya maklum jika ia dizalimi, namun bagaimana saya menolong padahal ia zalim?" Nabi menjawab: "Engkau mencegahnya atau menahannya dari kezaliman, itulah cara menolongnya."

Berdasarkan hadis di atas, maka mencegah orang tua ketika melakukan sesuatu yang diharamkan termasuk salah satu bentuk berbakti dan berbuat baik kepada keduanya. ${ }^{61}$

Dapat ditarik sebuah kesimpulan bahwa ketika seorang anak tidak mematuhi perintah orang tua yang akan menikahkannya dengan orang yang tidak disukainya, maka hal itu bukanlah merupakan bentuk durhaka kepada orang tua. Justru sebaliknya, tidak mematuhi orang tua dalam hal ini, kemudian menasehatinya dengan baik agar orang tua tidak melakukan pemaksaan untuk menikah dengan orang yang tidak dicintainya merupakan salah satu bentuk berbakti kepada orang tua. Sebaliknya seorang anak yang mematuhi perintah orang tua yang akan menikahkannya dengan orang yang tidak dicintainya tidak bisa dikatakan sebagai bentuk berbakti kepada orang tua, karena kepatuhan anak tersebut bukan atas dasar cinta kasih dan kemuliaan -sebagaimana yang diungkapkan al-Marâghî di atas-, melainkan karena lebih berdasar pada rasa takut kepada kedua orang tua dan keterpaksaan.

\section{Penutup}

Memilih suami merupakan hak yang diberikan oleh Syara' kepada seorang perempuan secara mutlak. Dengan demikian, ketika seorang bapak ataupun wali yang lain merampas hak itu dengan memaksa menikahkan anak perempuan dengan laki-laki yang tidak dicintainya, maka hal itu merupakan sebuah kejahatan.

Mayoritas ulama (Malikiyyah, Syafi'iyyah, Hanabilah) berpendapat bahwa wali menjadi rukun dalam sebuah akad nikah, sehingga jika akad nikah tidak melibatkan wali, maka nikahnya tidak

60 Al-Bukhârî, al-Jâmi' al-Shahîh h, Vol. 9 (Kairo: Da>r al-Sha‘b, 1987), 28.

61 Muha\}mmad bin S\{a>lih\} al-'Utsaymi>n, Fata>wa> Mawqi>' al-Alu>kah (t.t.: t.p., 1429 H.), fatwa no. 1245. 
sah. Adapun ulama H\{anafiyyah berpendapat bahwa wali bukan merupakan rukun dalam akad nikah, sehingga seorang perempuan boleh menikahkan dirinya sendiri. Namun, meskipun seorang perempuan (perawan maupun janda) berakal dan balighah mempunyai hak dalam melaksanakan akad nikahnya, tetap saja dianjurkan baginya untuk memasrahkan akad nikahnya kepada walinya. Seorang bapak boleh menikahkan anak perempuannya yang masih kecil (belum balighah) tanpa izinnya dengan syarat bahwa pernikahan itu membawa maslahah (kebaikan) bagi si anak dan tidak membahayakan si anak. Adapun bagi anak perempuan yang sudah balighah, maka orang tua tidak boleh menikahkannya secara paksa tanpa persetujuan darinya.

\section{Daftar Pustaka}

Abâdi, Muhammad bin Ya'qûb al-Fayrûz. al-Qâmûs al-Muhîth, t.t.: t.p., t.th.

'Abidîn, Ibn. Hasyiyah Râdd al-Mukhtâr, Beirut: Dar al-Fikr, 2000.

Afriqi, Ibn al-Mandzûr al-. Lisân al-'Arab, Beirut: Dar Sadir, t.th.

Alkhin, Musthafâ, Musthafâ al-Bughâ dan 'Alî al-Sarbajî. al-Fiqh alManhajî 'ala al-Madzhab al-Imâm al-Syâfi' $\hat{\imath}$, Surabaya: al-Fitrah, t.th.

Anshârî, Zakariyâ al-. Asna al-Mathâlib fi Syarh Raudlah al-Thâlib, Beirut: Dâr al-Kutub al-'Ilmiyah, 2000.

'Asqalânî, Ibn Hajar al-. al-Talkhîs al-Hâbir fi Takhrîj Ahâdîth al-Râfi'î alKabîr, Beirut: Dâr al-Kutub al-'Ilmiyah, 1989.

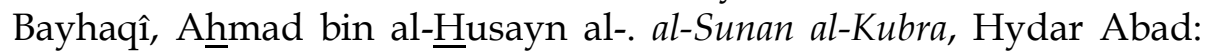
Majlis Dâ'irah Ma'ârif al-Nidzamiyah al-Kâ'inah, $1344 \mathrm{H}$.

Bukhârî, Muhammad bin Ismâ'îl. al-Jâmi' al-Shahîh h, Kairo: Dâr alSha'b, 1987.

Dâruquthnî, 'Ali bin 'Umar. Sunan al-Daruquthnî, t.t.: Mu'assasah alRisâlah, t.th.

Dhahabî, Muhammad bin Ahmad. Siyâr A'lâm al-Nubalâ', t.t.: Mu'assasah al-Risâlah, 1985.

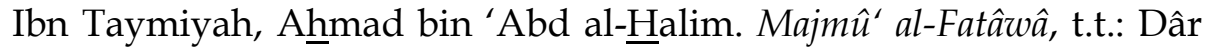
al-Wafâ', 2005.

Jazîrî, 'Abd al-Rahmân. al-Fiqh 'alâ al-Madzâhib al-Arba'ah, t.t.: t.tp, t.th. 
Marâghî, Ahmmad Musthafâ. Tafsîr al-Marâghĥ, Mesir: Syirkah Maktabah wa Mathba'ah Mushthafâ al-Bâbî al- $\underline{\text { Halibî wa }}$ Awlâdih, t.th.

Misri, Ibn Najim al. al-Bahr al-Ra'iq, Beirut: Dar al-Ma'rifah, t.th.

Nawawî, Yahya bin Syaraf al-. al-Minhâj Syarh Shahîh Muslim bin alHajjâj, Beirut: Dâr Ihyâ' al-Turâth al-'Arabî, 1392 H.

Naysaburî, Muslim bin al-Hajjâj al-. Shahîh Muslim, Beirut: Dâr al-Jail, t.th.

Qardlâwî, Yûsuf al-. Fatâwâa al-Mu'âshirah, t.t.: t.p., t.th.

Qazwaynî, Ibn Mâjah al-. Sunan Ibn Mâjah, t.t.: Maktabah Abî alMa'âthî, t.th.

Syaqr, 'Athiyyah. Fatâwâ al-Azhar, t.t.: Mawqi' Wizârah al-Awqâf alMishriyyah, t.th.

Sâbiq, al-Sayyid. Fiqh al-Sunnah, Beirut: Dâr al-Ma'rifah, 2010.

Syawkânî, Muhammad bin 'Alî al-. Nayl al-Awthâr min Ahâdîts Sayyid al-Akhyâr Syarh Muntaqâ al-Akhbâr, t.t.: Idârah al-Thibâ'ah alMunîriyah, t.th.

Syarbînî, al-Khatîb. Mughni al-Muhtaj, t.t.: t.p., t.th.

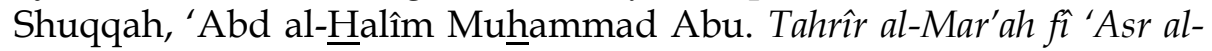
Risâlah, Kuwait: Dâr al-Qalam, 1999.

Sarkhâsi, Muhammad bin Abî Sahl al-. al-Mabsûth, Beirut: Dâr al-Fikr, 2000.

Sijistânî, Abû Dawûd al-. Sunan Abî Dawûd, Beirut: Dâr al-Kitâb al'Arabî, t.th.

Thahhân, Mahmûd al-. Taysîr Musthalah al-Hadîts. Beirut: Dar al-Fikr, t.th.

'Ubayd, Dalâl Kadzîm. Mafhûm Hurriyat al-Mar'ah fi Dlaw' al-Fikr alTarbawî al-Islâmî. Beirut: Kitab-Nashirun, 2011.

'Utsaymin, Muhammad bin Shâlih al-. Fatâwwâ Mawqi' al-Alûkah. t.t.: t.p., $1429 \mathrm{H}$.

Zabîdî, Murtadlâ al-. Tâj al-'Arûs, t.t.; Dâr al-Hidâyah, t.th.

http://www.bbc.co.uk/indonesia/dunia/2012/06/120608_forced_m

arriages.shtml)

http:/ / news.liputan6.com/read/688379/tragis-gadis-8-tahun-

korban-nikah-paksa-tewas-saat-malam-pertama

http:/ / www.tempo.co/read/news/2014/08/28/058602917/Kawin-

Paksa-Jadi-Penyebab-Tertinggi-Perceraian 